\title{
Reconstitution of an active human CENP-E motor
}

Benjamin Craske ${ }^{1}$, Thibault Legal ${ }^{1,2}$, Julie P.I. Welburn ${ }^{1^{*}}$

${ }^{1}$ Wellcome Trust Centre for Cell Biology, School of Biological Sciences, University of Edinburgh, Edinburgh EH9 3BF, Scotland, UK

${ }^{2}$ now Department of Anatomy and Cell Biology, 3640 Rue University, Montreal, McGill University, QC H3A 0C7, Canada

"Corresponding author

E-mail: Julie.Welburn@ed.ac.uk

Keywords: motor, mitosis, microtubule, motility, regulation, CENP-E, kinetochore

Running title:

Human CENP-E is regulated by its elongated stalk and tail 


\begin{abstract}
CENP-E is a large kinesin motor protein which plays pivotal roles in mitosis by facilitating chromosome capture, alignment and promoting microtubule flux in the spindle. So far, it has not been possible to obtain active human CENP-E to study its molecular properties. Xenopus CENP-E motor has been characterised in vitro and is used as a model motor, however its protein sequence differs significantly from human CENP-E. Here, we characterise human CENP-E motility in vitro. Full-length CENP-E exhibits an increase in run length and longer residency times on microtubules when compared to CENP-E motor truncations, indicating that the $\mathrm{C}$-terminal microtubule binding site enhances the processivity when the full-length motor is active. In contrast to constitutively active human CENP-E truncations, full-length human CENP-E has a reduced microtubule landing rate in vitro, suggesting that the non-motor coiled coil regions self-regulate motor activity. Together, we demonstrate that human CENP-E is a processive motor, providing a useful tool to study the mechanistic basis for how human CENP-E drives chromosome congression and spindle organisation during human cell division.
\end{abstract}




\section{Introduction}

Chromosome alignment and segregation is essential to ensure genomic stability. The mitotic spindle is the physical apparatus that allows the accurate alignment of chromosomes during mitosis. Following the disassembly of the nuclear envelope in prophase, chromosomes are captured by microtubules and aligned in the metaphase plate (Magidson et al., 2015; Pereira et al., 2018; Rodriguez-Rodriguez et al., 2018; Sacristan et al., 2018). However, chromosomes at the spindle poles often cannot biorient through this search and capture mechanism and use a dynein/CENP-E dependent pathway (Bancroft et al., 2014; Barisic et al., 2014). The microtubule motor protein CENP-E is recruited to the fibrous corona of unattached kinetochores, a large macromolecular structure that maximizes the microtubulebinding surface of kinetochores to favour microtubule capture (Cooke et al., 1997; Pereira et al., 2018; Rodriguez-Rodriguez et al., 2018; Sacristan et al., 2018). Upon microtubule capture, CENP-E walks towards microtubule plus ends and promotes the lateral to end-on conversion of kinetochores on microtubules (Shrestha and Draviam, 2013; Sikirzhytski et al., 2018; reviewed in Craske and Welburn, 2020). CENP-E is recruited to kinetochores through a rapid BubR1-dependent and a slower BubR1-independent pathway (Ciossani et al., 2018; Johnson et al., 2004; Legal et al., 2020). Inhibition or depletion of CENP-E in human cells increases the incidence of chromosome misalignments, causes spindle assembly checkpoint activation and results in a prometaphase arrest (Gudimchuk et al., 2013; Tanudji et al., 2004; Wood et al., 2010), highlighting the essential function of the kinetochorelocalized motor during chromosome congression. More recently the kinetochore-bound CENP-E population has been implicated in promoting microtubule flux in prometaphase (Steblyanko et al., 2020). CENP-E also localizes to the overlapping microtubules of the spindle midzone and midbody, suggesting roles for CENP-E during the later stages of mitosis (Yen et al., 1991).

Previous work to reconstitute the activity of native CENP-E fractionated from HeLa cells indicated that the full-length protein was inactive (DeLuca et al., 2001). Thus until now, biochemical characterisation studies and in vitro reconstitutions of CENP-E activity have used the Xenopus laevis CENP-E orthologue. $X$. laevis CENP-E displays processive motility along single microtubules in vitro and is required for chromosome alignment in egg extracts (Gudimchuk et al., 2013; Kim et al., 2008; Yardimci et al., 2008). This has provided important insights into how CENP-E functions at a molecular level. However, human and $X$. laevis CENP-E share only $49 \%$ sequence similarity. The human model system is often used for cell biology, functional and structural studies of human kinetochores and cell division. Currently it is not clear to what extend the large sequence differences provide properties to 
human CENP-E distinct from the Xenopus CENP-E orthologue to mediate chromosome segregation in humans. In this study, we report that both truncated and full-length human CENP-E motors are active. We find truncated CENP-E is constitutively active and processive in vitro, capable of unidirectional movement along microtubules. In contrast, only a fraction of full-length human CENP-E motors are active, yet more processive than truncated CENP-E upon a successful collision with the microtubule. This indicates that the long non-motor region interferes with the motile properties of full-length CENP-E in vitro. Overall, the reconstitution of active human CENP-E motors obtained in this study represent a useful ressource for the study of the mechanistic basis for chromosome segregation in humans.

\section{Results}

\section{Truncated human CENP-E constructs are motile and processive}

As human full-length CENP-E has been shown to be inactive (DeLuca et al., 2001), we first tested whether a minimal human CENP-E motor displayed any motility. We designed several $\mathrm{N}$-terminal truncations containing the motor domain. Human CENP-E is predicted to contain over 20 discontinuous coiled-coils within its stalk and $C$ terminus (Fig $1 \mathrm{~A}$ and $1 \mathrm{~B}$ ). The first putative coiled-coil of human CENP-E is predicted to form between residues 334401 (Fig 1A) by PairCoil2 (McDonnell et al., 2006). A minimal truncated Xenopus CENP-E ${ }_{1}$ 473 construct containing the motor domain, a single coiled-coil between residues 335-392 and terminating at Thr-473 with a C-terminal GFP tag, is processive in vitro (Kim et al., 2008). We therefore designed a similar construct of human CENP-E, which we refer to as CENP-E ${ }_{483}$, followed by two tandem mNeonGreen fluorophores for recombinant expression and purification from insect cells (Fig 1B and S1B).

Next, we tested whether human $\mathrm{CENP} \mathrm{E}_{483}$ walks processively on microtubules using in vitro reconstitution and single molecule imaging with TIRF (total internal reflection fluorescence) microscopy. Processive landing events of human $\mathrm{CENP}_{-\mathrm{E}_{483}}$ on immobilized GMPCPPstabilized microtubules were rare at the low nanomolar concentrations required for single molecule imaging (Fig 1C and 1D), in contrast to constitutively active Kinesin-1 (K560-GFP) (Fig 1D). The majority of $C$ ENP-E ${ }_{483}$ microtubule binding events were short-lived interactions, with only a small fraction undergoing continuous unidirectional movement along microtubules (Fig 1D). This suggested to us the motor may not be stable, despite eluting as a single peak by size-exclusion chromatography (Fig S1A). To test whether CENP-E $\mathrm{E}_{483}$ was a stable dimer, we analyzed the oligomeric status of purified CENP-E $\mathrm{E}_{483}$ by native PAGE. We detected the presence of two separate protein species migrating at approximately $\sim 100$ $\mathrm{kDa}$ and $\sim 230 \mathrm{kDa}$ (Fig 1E). Given that the predicted monomeric molecular weight of CENP- 
$\mathrm{E}_{483}$ is $109 \mathrm{kDa}$, this result indicates that purified CENP-E $\mathrm{E}_{483}$ exists dynamically as a mixture of monomers and dimers in solution (Fig 1E). Thus the first coiled-coil within the stalk of human CENP-E supports only weak dimerization of the motor, as previously reported for Xenopus CENP-E (Yardimci et al., 2008).

We next measured the behaviour of CENP- $\mathrm{E}_{483}$ motors in vitro at $50 \mathrm{nM}$, to increase the probability of detecting processive events. We found that human CENP-E $\mathrm{E}_{483}$ motors exhibited an average velocity of $144.2 \pm 7.7 \mathrm{~nm} / \mathrm{s}$ when moving unidirectionally on the microtubule (Fig 1F). This velocity was approximately 10-fold faster than a previously reported gliding speed for a truncated human CENP-E construct (Sardar et al., 2010). With a run length of $407.3 \mathrm{~nm}$ (95\% confidence interval, $\left.\mathrm{Cl}_{95}[386.9,430.1] \mathrm{nm}\right)$, we found that CENP-E $\mathrm{E}_{483}$ motors exhibited a relatively long residency time of $5.41 \mathrm{~s}$ (95\% confidence interval, $\mathrm{Cl}_{95}[5.29,6.56] \mathrm{s}$ ) on the microtubule lattice (Fig $1 \mathrm{G}$ and $1 \mathrm{H}$ ). Kymograph analysis indicated that human $C E N P-E_{483}$ often exhibited discontinuous motion and frequently paused during processive runs, with recorded velocities ranging from $16.4 \mathrm{~nm} / \mathrm{s}$ up to 388.9 $\mathrm{nm} / \mathrm{s}$ (Fig 1F). Similarly, heterogeneity has also been previously reported in the motility of

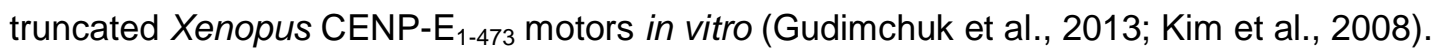

\section{Reconstitution of robust processive motility by human CENP-E through stabilization of a dimeric stalk}

To stabilize the CENP-E motor as a dimer, we artificially dimerized truncated human CENPE construct by fusing a GCN4 leucine zipper domain to the $C$ terminus of CENP- $E_{483}$ and

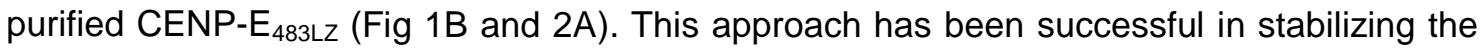
dimeric state of human KIF1A truncations and reconstituting the superprocessive motility of

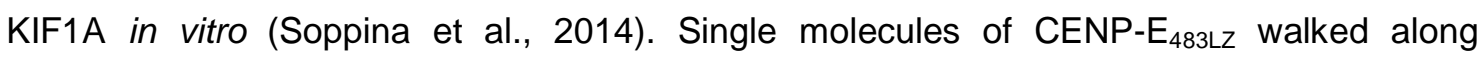
microtubules with an average velocity of $179.9 \pm 3.6 \mathrm{~nm} / \mathrm{s}$, similar to that measured for CENP-E $\mathrm{E}_{483}$ (Fig 2B - 2D, Movie 1). However, CENP-E ${ }_{483 L z}$ motors were more processive than the weakly dimeric CENP- $\mathrm{E}_{483}$, displaying a run length of $685.2 \mathrm{~nm}(95 \%$ confidence interval, $\mathrm{Cl}_{95}[661.4,710.7] \mathrm{nm}$ ) and a maximum recorded run of $4.4 \mu \mathrm{m}$ (Fig 2B - E). CENP$\mathrm{E}_{483 \mathrm{Lz}}$ motors demonstrated residency times of $6.36 \mathrm{~s}$ (95\% confidence interval, $\mathrm{Cl}_{95}[6.17$, 6.56] s) on the microtubule (Fig 2F). Similarly to CENP-E ${ }_{483}$, we found that processive runs

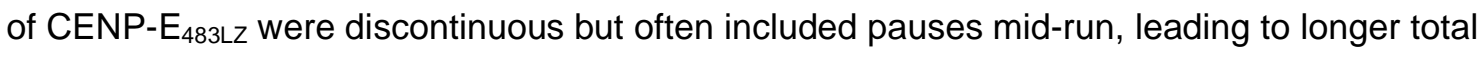
residency times on the microtubule before detachment (Fig 2B and 2F).

As full-length human CENP-E is a homodimer in solution (DeLuca et al., 2001), we hypothesized that the dimerization was stabilized by the multiple coiled coils within the native stalk region. In line with this, subsequent coiled-coils scored higher in Paircoil2 
probabilities than the first coiled-coil 334-401 (Fig 1A). This was confirmed by Alphafold2 which predicts residues $345-399$ to be coiled coils, although it does not predict them to dimerize with confidence (Mirdita et al., 2021). We generated a truncated CENP-E $\mathrm{E}_{754}$ containing five predicted coiled-coils present in the native stalk of CENP-E. We found that CENP-E ${ }_{754}$ was processive, with an average speed of $180.0 \pm 2.4 \mathrm{~nm} / \mathrm{s}$ (Fig $2 \mathrm{G}$ and Movie 2), similar to CENP-E $\mathrm{E}_{483 \mathrm{Lz}}$ and $\mathrm{CENP} \mathrm{E}_{483}$ (Fig 1F and 2D). Thus, the coiled-coils in the stalk of CENP-E stabilize homodimerization of the motor domains and facilitate processivity. Single molecule analysis of CENP- $E_{754}$ on microtubules revealed a run length of $703.3 \mathrm{~nm}$ (95\% confidence interval, $\left.\mathrm{Cl}_{95}[683.53,724.11] \mathrm{nm}\right)$ and a residency time of $5.3 \mathrm{~s}(95 \%$ confidence interval, $\mathrm{Cl}_{95}[5.07,5.56] \mathrm{s}$ ) (Fig 2D - I). Photobleaching assays and intensity analysis indicated that CENP- $E_{754}$ motors typically bleached in 3 or 4 steps and their initial intensities were similar to a purified K560 construct fused to two tandem mNeonGreen tags, referred to as $\mathrm{K} 560-2 \mathrm{mNG}$ (Fig $2 \mathrm{C}$ and $2 \mathrm{~J}-\mathrm{L}$ ). This indicates for the first time that the human CENP-E motor is an active processive motor.

\section{Full-length human CENP-E is predominantly inactive but becomes processive upon microtubule binding}

Previous work reported that the full-length human CENP-E motor purified from human cells is inactive in vitro (DeLuca et al., 2001). We expressed and purified full-length human CENP-E-mNeonGreen, referred to as CENP- $E_{\mathrm{FL}}$, from insect cells (Fig 3A). The $692 \mathrm{kDa}$ dimeric CENP-E $\mathrm{E}_{\mathrm{FL}}$ eluted as an elongated molecule by size-exclusion chromatography. We next carried out microtubule gliding assays by tethering CENP-E to the coverslip and flowing in free microtubules in solution with ATP, to assess whether CENP- $E_{F L}$ is active. Many microtubules did not glide along the coverslip, despite binding to immobilized full-length motors. Notably, some microtubules bound and pivoted on the surface (Movie 3), as previously published (DeLuca et al., 2001). A subset of microtubules glided along the coverslip surface, with an average velocity of $115.7 \mathrm{~nm} / \mathrm{s}$ (Fig 3B), in agreement with our single molecule velocities for truncated human CENP-E motors.

We next tested whether single CENP- $\mathrm{E}_{\mathrm{FL}}$ motors displayed any motility on microtubules in vitro, using $12.5 \mathrm{nM}$ in our reconstitution assays. We found that CENP-E $\mathrm{FL}_{\mathrm{FL}}$ motors predominantly bound to the lattice in a static manner. However, we observed some single molecules moving processively along the microtubule (Fig 3C - I and Movie 4). In contrast to CENP- $E_{754}$, CENP- $E_{\mathrm{FL}}$ run length increased 1.8-fold with a run length of $1258.9 \mathrm{~nm}(95 \%$ confidence interval, $\left.\mathrm{Cl}_{95}[1159.42,1377.22] \mathrm{nm}\right)$ and a 7 -fold increase in residency time to $37.1 \mathrm{~s}\left(95 \%\right.$ confidence interval, $\left.\mathrm{Cl}_{95}[36.04,38.15] \mathrm{s}\right)$ (Fig $3 \mathrm{E}$ and $3 \mathrm{~F}$ ). We frequently observed discontinuity in CENP- $\mathrm{E}_{\mathrm{FL}}$ motion on the microtubule and variation in the recorded 
velocities (Fig 3D). CENP-E $E_{F L}$ displayed a bimodal distribution of velocities and the histogram data were fitted to two overlapping gaussians (Fig 3D). The majority of motile CENP- $E_{F L}$ molecules were slow-moving population of motors, moving at $46.4 \pm 1.88 \mathrm{~nm} / \mathrm{s}$ and would often exhibit paused phases during a single processive run (Fig 3D). Yet, a distinct population of CENP- $\mathrm{E}_{\mathrm{FL}}$ motors were fast-moving at an average velocity of $157.98 \pm$ $10.77 \mathrm{~nm} / \mathrm{s}$, similar to the constitutively active truncated CENP-E constructs characterized above (Fig 2D and 2G). We also found that full-length CENP-E landed on the lattice much less frequently than truncated motors (Fig $4 \mathrm{~A}$ and $4 \mathrm{~B}$ ). $C E N P-E_{\mathrm{FL}}$ had a landing rate of 0.147 \pm 0.008 events $\mu \mathrm{m}^{-1} \mathrm{~min}^{-1}$ whereas CENP- $E_{754}$ had a higher landing rate of $0.392 \pm 0.008$ events $\mu \mathrm{m}^{-1} \mathrm{~min}^{-1}$ (Fig 4A). Importantly, the processive landing rate of CENP-E $E_{\mathrm{FL}}$ was 0.009 \pm 0.002 events $\mu \mathrm{m}^{-1} \mathrm{~min}^{-1}$ which was approximately 20 -fold lower than the $0.210 \pm 0.012$ events $\mu \mathrm{m}^{-1} \mathrm{~min}^{-1}$ observed for truncated CENP-E ${ }_{754}$ motors (Fig 4B). Thus, our in vitro reconstitution experiments indicate that a large fraction of purified full-length CENP-E molecules are not active in our assay conditions. However, purified full-length human CENP$\mathrm{E}$ molecules that are active, are highly processive upon a successful collision with the microtubule (Fig 4C).

\section{Discussion}

Taken together, we show that the human CENP-E motor is an active and processive plusend directed motor. The majority of full-length CENP-E motors move at a slow average velocity of $46.4 \pm 1.88 \mathrm{~nm} / \mathrm{s}$, with a fraction moving at a comparable velocity to constitutively active truncated motors (Fig 2D, 2G and 3D). Similar behaviour has been previously reported for kinesin-1, whereby motile full-length KIF5B molecules exhibit discontinuity in their processive motion and display a much slower velocity than the KIF5B tail-truncated mutant (Friedman and Vale, 1999). Processive full-length CENP-E motors exhibited higher run lengths and residency times than truncated CENP-E motors. Here we show this is due to the increased stabilization of the dimer through the extensive coiled coils when compared to truncated CENP-E $\mathrm{E}_{483}$. The increase in processivity may also be due to the presence of a non-motor microtubule binding site at the far $\mathrm{C}$ terminus of full-length CENP-E, as CENP$E_{754}$ lacks this region (Liao et al., 1994; Musinipally et al., 2013; Welburn, 2013). Many kinesins have a second non-specific microtubule binding site which increase their residency time and processivity (Mayr et al., 2011; McHugh et al., 2018; Zhernov et al., 2020).

Our observation that full-length CENP-E activity is relatively variable, may explain why previous attempts to reconstitute microtubule gliding activity of HeLa extract purified CENPE were unsuccessful (DeLuca et al., 2001). The coiled coils of full-length CENP-E may increase the conformational entropy of the motor in vitro and interfere with microtubule 
binding and processivity. In vitro reconstitutions with full-length Xenopus CENP-E indicate that the fraction of active motor is increased when coupled to a bead in vitro, indicating a potential mechanism where engagement of the $C$ terminus interacting with a cargo (i.e. the bead in that study) promotes CENP-E motor activity (Gudimchuk et al., 2013). We propose interacting partners at the outer corona or the kinetochores could reorganize the coiled coils regions, stabilize an active conformation of CENP-E and co-ordinate its processive transport activity similarly to activation of other kinesin motors (Cho et al., 2009; Coy et al., 1999; Henrichs et al., 2020; Hooikaas et al., 2019; McKenney et al., 2014). Several proteins have been described to interact with CENP-E at kinetochores including BubR1, CLASP1/2, PP1 and CENP-F (Chan et al., 1998; Ciossani et al., 2018; Kim et al., 2010; Kurasawa et al., 2004; Maffini et al., 2009). Super-resolution imaging of kinetochores indicates CENP-E has a compact conformation at the outer corona and kinetochores, close to Ndc80, CENP-F and Spindly (Varma et al., 2013; Wan et al., 2009). In vitro, full-length Xenopus CENP-E under load stalls at an average force of $4.6 \mathrm{pN}$ but surprisingly maintains a short length of $45 \mathrm{~nm}$ when transporting beads under the application of a sidewards force (Gudimchuk et al., 2018). Thus activated CENP-E may maintain a compact conformation during transport of heavy-load cargoes, which includes pulling of chromosomes towards the equator (Kapoor et al., 2006) and potentially sliding cross-linked microtubules of the spindle (Risteski et al., 2021; Steblyanko et al., 2020).

Overall human CENP-E appears to be a less efficient motor than the Xenopus orthologue of CENP-E. Here we show that truncated human CENP-E has an average velocity of $179.9 \pm$ $2.4 \mathrm{~nm} / \mathrm{s}$ and a typical run length of $703.3 \mathrm{~nm}$. Truncated Xenopus CENP-E 473 was first reported as a slow motor with an average speed of $8 \mathrm{~nm} / \mathrm{s}$ (Kim et al., 2008). However, subsequent reconstitutions with truncated Xenopus CENP-E $\mathrm{E}_{473}$ and full-length Xenopus CENP-E demonstrated 50 -fold higher velocities of approximately $300 \mathrm{~nm} / \mathrm{s}$ and $400 \mathrm{~nm} / \mathrm{s}$ respectively, and average run lengths between 1.5 - $2.5 \mu \mathrm{m}$ (Barisic et al., 2015; Gudimchuk et al., 2013). The presence of the C-terminal microtubule binding site in full-length Xenopus CENP-E was not reported to enhance CENP-E processivity, in contrast to what we observe for human CENP-E (Fig 2D, 2G and 3D) (Gudimchuk et al., 2013). These discrepancies could be attributed to species divergence. For example, human and Xenopus CENP-E proteins share only $49 \%$ sequence similarity across their entire length. Xenopus laevis CENP-E is 253 residues longer than human CENP-E, with a large insertion C-terminal to the kinetochore-targeting domain. It is also likely we are missing regulatory partners that would stabilize the coil-coiled and kinetochore-binding region of CENP-E to optimize motor activity. Recent studies have highlighted previously unappreciated localization patterns of human CENP-E at overlapping microtubule bundles and to the detachable fibrous corona in human 
cells (Pereira et al., 2018; Sacristan et al., 2018; Steblyanko et al., 2020). Whether Xenopus CENP-E is also recruited to these subcellular regions, or whether this is a human-specific CENP-E function, is not currently known. Given that CENP-E interacts with multiple partners in distinct locations, it will be important to define how the regulatory partners regulate CENP. $E$ structure and function, and how they can affect the load-bearing capacities of CENP-E to fulfil its mitotic functions. 


\section{Experimental procedures}

\section{Protein expression and purification}

The sequences for the CENP-E-mNeonGreen gene were made synthetically for this study and are deposited on addgene. mNeonGreen gene was synthesized by Genewiz. Three synthetic DNA fragments of human CENP-E, codon optimised for insect cell expression, were ordered from Gen9. Each DNA fragment contained $100 \mathrm{bp}$ of overlapping fragments and were amplified by PCR and purified. DNA was transformed into competent BY4741 Saccharomyces cerevisiae as described in (Gietz and Schiestl, 2007) using an equimolar ratio of each 3 fragments and pRS415 vector, previously linearised with Smal. Briefly, PEG, Lithium Acetate and herring sperm DNA were incubated with the DNA to be assembled and added to $50 \mu \mathrm{L}$ of competent cells. After a 30 -minute incubation at $30^{\circ} \mathrm{C}$, DMSO was added and the cells were heat shocked at $42^{\circ} \mathrm{C}$. The cells were then spun down, re-suspended in $400 \mu \mathrm{L}$ of $5 \mathrm{mM} \mathrm{CaCl}_{2}$ and plated on Synthetic Defined medium without Leucine. Genes encoding full-length Homo sapiens CENP-E were amplified by PCR and inserted into a pFastBac1 vector backbone, with a $3 \mathrm{C}$ PreScission Protease cleavage site, mNeonGreen fusion protein and a hexahistidine tag located at the $\mathrm{C}$ terminus. Truncated Homo sapiens CENP-E constructs were generated by PCR amplification of the codon optimised CENP-E sequence as a template. PCR products were digested ligated into a pFastBac1 vector containing $2 x$ tandem $\mathrm{mNeonGreen}$ fusion proteins and a hexahistidine tag at the $\mathrm{C}$ terminus. K560-2mNG was generated by PCR amplifying the Homo sapiens KIF5B sequence (amino acids 1-560) and inserting into a pET3aTR vector (Tan, 2001) containing $2 \mathrm{x}$ tandem $\mathrm{mNeonGreen}$ fusion proteins and a hexahistidine tag at the $\mathrm{C}$ terminus.

Recombinant human CENP-E proteins were expressed using the baculovirus system in Sf9 cells. Cells were harvested 48-62 hours after infection and stored at $-70{ }^{\circ} \mathrm{C}$ until use. Harvested cells were resuspended in CENP-E lysis buffer (50 mM HEPES pH 7, $300 \mathrm{mM}$ $\mathrm{KCl}, 40 \mathrm{mM}$ imidazole, $1 \mathrm{mM} \mathrm{MgCl}$, $1 \mathrm{mM}$ EGTA, $0.1 \mathrm{mM}$ ATP, $5 \mathrm{mM}$ betamercaptoethanol) supplemented with $1 \mathrm{mM}$ PMSF, $5 \mu \mathrm{g} / \mathrm{mL}$ DNase and 1x cOmplete protease inhibitor tablet per $50 \mathrm{~mL}$. Cells were lysed in a dounce homogeniser with 30-40 strokes. The lysate was cleared by centrifugation at 40,000 rpm in a Type $45 \mathrm{Ti}$ rotor for 60 minutes at $4{ }^{\circ} \mathrm{C}$ and applied onto a pre-equilibrated HisTrap HP column (GE Healthcare) in CENP-E lysis buffer at $4{ }^{\circ} \mathrm{C}$. HisTrap columns were washed with 40 column volumes of CENP-E lysis buffer. Proteins were eluted with $250 \mathrm{mM}$ imidazole. Elution fractions were concentrated, centrifuged at $13,300 \mathrm{rpm}$ for $15 \mathrm{mins}$ at $4^{\circ} \mathrm{C}$ and then loaded onto a 
Superose 6 Increase 10/300 column (GE Healthcare) pre-equilibrated with CENP-E gel filtration buffer (50 mM HEPES pH 7, $300 \mathrm{mM} \mathrm{KCl,} 1 \mathrm{mM} \mathrm{MgCl} 2,1 \mathrm{mM}$ EGTA, $0.1 \mathrm{mM}$ ATP, $1 \mathrm{mM}$ DTT). Fresh CENP-E proteins were used for all in vitro motility assays due to deterioration in activity after freezing.

Homo sapiens K560-GFP was purified using a previously described protocol (Case et al., 1997) omitting the final microtubule bind and release step, snap frozen and stored at $-70^{\circ} \mathrm{C}$. K560-2mNG was transformed in E. coli BL21 CodonPlus (DE3) RIL (Agilent Technologies). Transformed BL21 cells were grown to $\mathrm{OD}_{600}=0.6$ then cooled to $20{ }^{\circ} \mathrm{C}$ before induction with $0.5 \mathrm{mM}$ IPTG for $3-4$ hours at $20^{\circ} \mathrm{C}$. Frozen pellets were resuspended in $\mathrm{K} 560$ lysis buffer $(50 \mathrm{mM}$ Tris $\mathrm{pH}$ 7.5, $300 \mathrm{mM} \mathrm{KCl}, 40 \mathrm{mM}$ imidazole, $1 \mathrm{mM} \mathrm{MgCl} 2,1 \mathrm{mM}$ EGTA, 0.1 mM ATP, $5 \mathrm{mM}$ beta-mercaptoethanol) supplemented with $1 \mathrm{mM}$ PMSF and 1x cOmplete protease inhibitor tablet per $50 \mathrm{~mL}$, and sonicated. The lysate was cleared by centrifugation at $58,000 \mathrm{~g}$ for 50 minutes at $6{ }^{\circ} \mathrm{C}$ in a JA25:50 rotor. The supernatant was incubated with Ni-NTA beads (Thermo) for 1.5 hours at $4 \mathrm{C}$. Beads were washed with 40 column volumes of K560 lysis buffer and proteins were eluted with $250 \mathrm{mM}$ imidazole. Elution fractions were concentrated and loaded onto a Superose 6 Increase 10/300 column (GE Healthcare) preequilibrated with $\mathrm{K} 560$ gel filtration buffer $(50 \mathrm{mM}$ Tris $\mathrm{pH} 7.5,300 \mathrm{mM} \mathrm{KCl}, 1 \mathrm{mM} \mathrm{MgCl} 2,1$ mM EGTA, $0.1 \mathrm{mM}$ ATP, $1 \mathrm{mM}$ DTT). Fractions containing K560-2mNG were snap frozen with $10 \%$ glycerol and stored at $-70{ }^{\circ} \mathrm{C}$.

\section{TIRF microscopy}

Microscopy was performed on a Zeiss Axio Observer Z1 TIRF microscope using a $100 \times$ NA 1.46 objective equipped with a Photometrics Evolved Delta EMCCD camera and controlled by Zen Blue 2.3 software. For single molecule experiments a $1.6 \mathrm{x}$ tube lens was used. The environmental chamber was incubated at $30{ }^{\circ} \mathrm{C}$ for all experiments. Coverslips used for motility assays were silanised as in (McHugh et al., 2018). Flow chambers were prepared by attaching a silanised coverslip to a microscopy slide with double-sided sticky tape. 4 sample flow chambers were constructed per microscopy slide, each with a volume of 7-8 $\mu \mathrm{L}$. Rhodamine microtubules were captured using a $561 \mathrm{~nm}$ laser with $15 \%$ intensity, $75 \mathrm{~ms}$ exposure. Images of mNeonGreen and GFP tagged motors were captured using a $488 \mathrm{~nm}$ laser with $50 \%$ intensity, $100 \mathrm{~ms}$ exposure and a frame rate of 0.12 frames per second.

For all in vitro motility experiments, $0.2 \mathrm{mg} / \mathrm{mL}$ GMPCPP (Jena Biosciences) microtubule seeds containing 7\% rhodamine-tubulin (Cytoskeleton Inc., TL590M-B,) were polymerised in BRB80 (80 mM PIPES pH 6.9, $1 \mathrm{mM}$ EGTA, $1 \mathrm{mM} \mathrm{MgCl}_{2}$ ) for 1 hour at $37^{\circ} \mathrm{C}$, followed by centrifugation at $13,300 \mathrm{rpm}$ for 10 minutes and then resuspended in BRB80. For gliding 
assays, anti-His tag antibodies (Raybiotech, 168-10481) at a 1:10 dilution in BRB80 were first introduced to the chamber. Next, $40 \mu \mathrm{L}$ of $1 \%$ Pluronic F-127 (Sigma Aldrich) in BRB80 was washed through the chamber and incubated for 5 minutes. $200 \mathrm{nM}$ of purified kinesin motors were then added to the chamber in BRB80 supplemented with 2 mM ATP. Chambers were then washed with $1 \mathrm{mg} / \mathrm{mL}$ casein (Sigma Aldrich) before a 1:25 dilution of GMP-CPP microtubules was added in final assay mix (80 mM PIPES pH 6.9, $5 \mathrm{mM} \mathrm{MgCl}_{2}, 2$ $\mathrm{mM}$ ATP, $1 \mathrm{mM}$ DTT and an oxygen scavenger mix: $0.2 \mathrm{mg} / \mathrm{ml}$ glucose oxidase, 0.035 $\mathrm{mg} / \mathrm{ml}$ catalase, $4.5 \mathrm{mg} / \mathrm{ml}$ glucose, and $0.1 \%$ beta-mercaptoethanol).

For single molecule motility assays, anti- $\beta$-tubulin antibodies (Sigma-Aldrich, T718) at a $1: 10$ dilution in BRB80 were first introduced to the chamber. Next, $40 \mu \mathrm{L}$ of $1 \%$ Pluronic F127 in BRB80 was washed through the chamber and incubated for 5 minutes. GMPCPP microtubules were diluted 1:50 in BRB80 and then added to the chamber for 5 minutes. Chambers were then washed with $1 \mathrm{mg} / \mathrm{mL}$ casein (Sigma Aldrich). Freshly purified motors were then added in final assay mix at concentrations indicated in the figure legends and chambers sealed with nail varnish. For photobleaching and intensity analysis, $0.5 \mathrm{nM}$ of fluorescently tagged motor was added to silanised coverslips and allowed to non-specifically adsorb to the surface. After 3 minutes, BRB80 supplemented with oxygen scavenger mix was flown through the chamber to wash away non-adsorbed motors. The sample chamber was imaged using the same conditions as described for single molecule assays.

\section{Image processing and analysis}

Kymographs were manually generated in ImageJ (Schneider et al., 2012). Gliding velocities, single molecule velocities, run lengths and residency times were measured from these kymographs. Data are collected from at least two independent experiments using motors from separate protein purifications. Histograms were generated from raw velocity data and fit to a gaussian distribution in MATLAB (Mathworks). For run lengths and residency times determination, cumulative frequency distributions were generated using the ecdf function in MATLAB and fit to a single exponential distribution. Run length and residency times were represented by the decay constant. Landing rates were determined at a concentration of 3.5 $\mathrm{nM}$ for each dimeric motor. Welch's t-tests were carried out in Graphpad Prism (GraphPad Software). Aggregates as determined from their initial intensity were excluded from analysis. Where necessary, images were also corrected for stage drift using the ImageJ Manual Drift Correction plug-in.

A custom ImageJ macro was developed for analysis of photobleaching steps (https://github.com/bcraske/lmageJ). Briefly, individual fluorescent spots adsorbed to 
coverslips were manually selected using the multi-point tool in ImageJ. Next, a 4 x 4 pixel square was assigned to the $\mathrm{ROI}$ and the average intensity was measured over time using the plot $Z$ axis profile function. Background fluorescence was subtracted by assigning a $10 \mathrm{x}$ 10 square centred around the $\mathrm{ROI}$, excluding the $4 \times 4$ pixel area, using the plot $Z$ axis profile function. Discrete photobleaching steps were manually counted from the plotted results. Initial intensity values were calculated as the average fluorescence intensity from a single adsorbed motor over the first 5 frames of imaging and the data was plotted as a histogram in MATLAB. 


\section{Acknowledgements}

JW is supported by a Wellcome Senior Reseach Fellowship (207430). JW is also a EMBO Young Investigator. B.C. is supported by the Biotechnology and Biological Sciences Research Council (BBSRC) [grant number BB/M010996/1]. The Wellcome Centre for Cell Biology is supported by core funding from the Wellcome Trust (203149).

\section{Author contributions}

JW designed the project. BC performed experiments with CENP-E. TL designed and assembled the CENP-E gene into pFastBac plasmid from gblocks optimized for insect cell expression. BC and JW performed data analysis and interpretation. BC and JW wrote the manuscript. 


\section{References}

Bancroft, J., Auckland, P., Samora, C.P., and McAinsh, A.D. (2014). Chromosome congression is promoted by CENP-Q- and CENP-E-dependent pathways. J. Cell Sci. 128, 171-184.

Barisic, M., Aguiar, P., Geley, S., and Maiato, H. (2014). Kinetochore motors drive congression of peripheral polar chromosomes by overcoming random arm-ejection forces. Nat. Cell Biol. 16, 1249-1256.

Barisic, M., Silva e Sousa, R., Tripathy, S.K., Magiera, M.M., Zaytsev, A. V., Pereira, A.L., Janke, C., Grishchuk, E.L., and Maiato, H. (2015). Microtubule detyrosination guides chromosomes during mitosis. Science. 348, 799-803.

Case, R.B., Pierce, D.W., Hom-Booher, N., Hart, C.L., and Vale, R.D. (1997). The Directional Preference of Kinesin Motors Is Specified by an Element outside of the Motor Catalytic Domain. Cell 90, 959-966.

Chan, G.K.T., Schaar, B.T., and Yen, T.J. (1998). Characterization of the Kinetochore Binding Domain of CENP-E Reveals Interactions with the Kinetochore Proteins CENP-F and hBUBR1. J. Cell Biol. 143, 49-63.

Cho, K., Yi, H., Desai, R., Hand, A.R., Haas, A.L., and Ferreira, P.A. (2009). RANBP2 is an allosteric activator of the conventional kinesin $\square 1$ motor protein, KIF5B, in a minimal cell $\square$ free system. EMBO Rep. 10, 480-486.

Ciossani, G., Overlack, K., Petrovic, A., Huis in 't Veld, P.J., Koerner, C., Wohlgemuth, S., Maffini, S., and Musacchio, A. (2018). The kinetochore proteins CENP-E and CENP-F directly and specifically interact with distinct BUB mitotic checkpoint Ser/Thr kinases. J. Biol. Chem. 293, 10084-10101.

Cooke, C.A., Schaar, B., Yen, T.J., and Earnshaw, W.C. (1997). Localization of CENP-E in the fibrous corona and outer plate of mammalian kinetochores from prometaphase through anaphase. Chromosoma 106, 446-455.

Coy, D.L., Hancock, W.O., Wagenbach, M., and Howard, J. (1999). Kinesin's tail domain is an inhibitory regulator of the motor domain. Nat. Cell Biol. 1, 288-292.

Craske, B., and Welburn, J.P.I. (2020). Leaving no-one behind: how CENP-E facilitates chromosome alignment. Essays Biochem. 64, 313-324.

DeLuca, J.G., Newton, C.N., Himes, R.H., Jordan, M.A., and Wilson, L. (2001). Purification and Characterization of Native Conventional Kinesin, HSET, and CENP-E from Mitotic HeLa Cells. J. Biol. Chem. 276, 28014-28021.

Friedman, D.S., and Vale, R.D. (1999). Single-molecule analysis of kinesin motility reveals regulation by the cargo-binding tail domain. Nat. Cell Biol. 1, 293-297. 
Gietz, R.D., and Schiestl, R.H. (2007). High-efficiency yeast transformation using the LiAc/SS carrier DNA/PEG method. Nat. Protoc. 2, 31-34.

Gudimchuk, N., Vitre, B., Kim, Y., Kiyatkin, A., Cleveland, D.W., Ataullakhanov, F.I., and Grishchuk, E.L. (2013). Kinetochore kinesin CENP-E is a processive bi-directional tracker of dynamic microtubule tips. Nat. Cell Biol. 15, 1079-1088.

Gudimchuk, N., Tarasovetc, E. V., Mustyatsa, V., Drobyshev, A.L., Vitre, B., Cleveland, D.W., Ataullakhanov, F.I., and Grishchuk, E.L. (2018). Probing Mitotic CENP-E Kinesin with the Tethered Cargo Motion Assay and Laser Tweezers. Biophys. J. 114, 2640-2652.

Henrichs, V., Grycova, L., Barinka, C., Nahacka, Z., Neuzil, J., Diez, S., Rohlena, J., Braun, M., and Lansky, Z. (2020). Mitochondria-adaptor TRAK1 promotes kinesin-1 driven transport in crowded environments. Nat. Commun. 11, 3123.

Hooikaas, P.J., Martin, M., Mühlethaler, T., Kuijntjes, G., Peeters, C.A.E., Katrukha, E.A., Ferrari, L., Stucchi, R., Verhagen, D.G.F., van Riel, W.E., et al. (2019). MAP7 family proteins regulate kinesin-1 recruitment and activation. J. Cell Biol. 218, 1298-1318.

Johnson, V.L., Scott, M.I.F., Holt, S. V., Hussein, D., and Taylor, S.S. (2004). Bub1 is required for kinetochore localization of BubR1, Cenp-E, Cenp-F and Mad2, and chromosome congression. J. Cell Sci. 117, 1577-1589.

Kapoor, T.M., Lampson, M.A., Hergert, P., Cameron, L., Cimini, D., Salmon, E.D., McEwen, B.F., and Khodjakov, A. (2006). Chromosomes Can Congress to the Metaphase Plate Before Biorientation. Science. 311, 388-391.

Kim, Y., Heuser, J.E., Waterman, C.M., and Cleveland, D.W. (2008). CENP-E combines a slow, processive motor and a flexible coiled coil to produce an essential motile kinetochore tether. J. Cell Biol. 181, 411-419.

Kim, Y., Holland, A.J., Lan, W., and Cleveland, D.W. (2010). Aurora Kinases and Protein Phosphatase 1 Mediate Chromosome Congression through Regulation of CENP-E. Cell 142, 444-455.

Kurasawa, Y., Earnshaw, W.C., Mochizuki, Y., Dohmae, N., and Todokoro, K. (2004). Essential roles of KIF4 and its binding partner PRC1 in organized central spindle midzone formation. EMBO J. 23, 3237-3248.

Legal, T., Hayward, D., Gluszek-Kustusz, A., Blackburn, E.A., Spanos, C., Rappsilber, J., Gruneberg, U., and Welburn, J.P.I. (2020). The C-terminal helix of BubR1 is essential for CENP-E-dependent chromosome alignment. J. Cell Sci. 133.

Liao, H., Li, G., and Yen, T.J. (1994). Mitotic Regulation of Microtubule Cross-Linking Activity of CENP-E Kinetochore Protein. Science. 265, 394-398.

Maffini, S., Maia, A.R.R., Manning, A.L., Maliga, Z., Pereira, A.L., Junqueira, M., Shevchenko, A., Hyman, A., Yates, J.R., Galjart, N., et al. (2009). Motor-Independent Targeting of CLASPs to Kinetochores by CENP-E Promotes Microtubule Turnover and 
Poleward Flux. Curr. Biol. 19, 1566-1572.

Magidson, V., Paul, R., Yang, N., Ault, J.G., O’Connell, C.B., Tikhonenko, I., McEwen, B.F., Mogilner, A., and Khodjakov, A. (2015). Adaptive changes in the kinetochore architecture facilitate proper spindle assembly. Nat. Cell Biol. 17, 1134-1144.

Mayr, M.I., Storch, M., Howard, J., and Mayer, T.U. (2011). A Non-Motor Microtubule Binding Site Is Essential for the High Processivity and Mitotic Function of Kinesin-8 Kif18A. PLoS One 6, e27471.

McDonnell, A. V., Jiang, T., Keating, A.E., and Berger, B. (2006). Paircoil2: improved prediction of coiled coils from sequence. Bioinformatics 22, 356-358.

McHugh, T., Gluszek, A.A., and Welburn, J.P.I. (2018). Microtubule end tethering of a processive kinesin-8 motor Kif18b is required for spindle positioning. J. Cell Biol. 217, 24032416.

McKenney, R.J., Huynh, W., Tanenbaum, M.E., Bhabha, G., and Vale, R.D. (2014).

Activation of cytoplasmic dynein motility by dynactin-cargo adapter complexes. Science. 345, 337-341.

Mirdita, M., Schütze, K., Moriwaki, Y., Heo, L., Ovchinnikov, S., and Steinegger, M. (2021). ColabFold - Making protein folding accessible to all. BioRxiv.

Musinipally, V., Howes, S., Alushin, G.M., and Nogales, E. (2013). The Microtubule Binding Properties of CENP-E's C-Terminus and CENP-F. J. Mol. Biol. 425, 4427-4441.

Pereira, C., Reis, R.M., Gama, J.B., Celestino, R., Cheerambathur, D.K., Carvalho, A.X., and Gassmann, R. (2018). Self-Assembly of the RZZ Complex into Filaments Drives Kinetochore Expansion in the Absence of Microtubule Attachment. Curr. Biol. 28, 34083421.e8.

Risteski, P., Božan, D., Jagrić, M., Bosilj, A., Pavin, N., and Tolić, I.M. (2021). Coordinated poleward flux of sister kinetochore fibers drives chromosome alignment. BioRxiv.

Rodriguez-Rodriguez, J.-A., Lewis, C., McKinley, K.L., Sikirzhytski, V., Corona, J., Maciejowski, J., Khodjakov, A., Cheeseman, I.M., and Jallepalli, P. V. (2018). Distinct Roles of RZZ and Bub1-KNL1 in Mitotic Checkpoint Signaling and Kinetochore Expansion. Curr. Biol. 28, 3422-3429.e5.

Sacristan, C., Ahmad, M.U.D., Keller, J., Fermie, J., Groenewold, V., Tromer, E., Fish, A., Melero, R., Carazo, J.M., Klumperman, J., et al. (2018). Dynamic kinetochore size regulation promotes microtubule capture and chromosome biorientation in mitosis. Nat. Cell Biol. 20, 800-810.

Sardar, H.S., Luczak, V.G., Lopez, M.M., Lister, B.C., and Gilbert, S.P. (2010). Mitotic Kinesin CENP-E Promotes Microtubule Plus-End Elongation. Curr. Biol. 20, 1648-1653. Schneider, C.A., Rasband, W.S., and Eliceiri, K.W. (2012). NIH Image to ImageJ: 25 years of image analysis. Nat. Methods 9, 671-675. 
Shrestha, R.L., and Draviam, V.M. (2013). Lateral to End-on Conversion of ChromosomeMicrotubule Attachment Requires Kinesins CENP-E and MCAK. Curr. Biol. 23, 1514-1526. Sikirzhytski, V., Renda, F., Tikhonenko, I., Magidson, V., McEwen, B.F., and Khodjakov, A. (2018). Microtubules assemble near most kinetochores during early prometaphase in human cells. J. Cell Biol. 217, 2647-2659.

Soppina, V., Norris, S.R., Dizaji, A.S., Kortus, M., Veatch, S., Peckham, M., and Verhey, K.J. (2014). Dimerization of mammalian kinesin-3 motors results in superprocessive motion.

Proc. Natl. Acad. Sci. 111, 5562-5567.

Steblyanko, Y., Rajendraprasad, G., Osswald, M., Eibes, S., Jacome, A., Geley, S., Pereira, A.J., Maiato, H., and Barisic, M. (2020). Microtubule poleward flux in human cells is driven by the coordinated action of four kinesins. EMBO J. 39, 1-22.

Tan, S. (2001). A Modular Polycistronic Expression System for Overexpressing Protein Complexes in Escherichia coli. Protein Expr. Purif. 21, 224-234.

Tanudji, M., Shoemaker, J., L'Italien, L., Russell, L., Chin, G., and Schebye, X.M. (2004). Gene Silencing of CENP-E by Small Interfering RNA in HeLa Cells Leads to Missegregation of Chromosomes after a Mitotic Delay. Mol. Biol. Cell 15, 3771-3781.

Varma, D., Wan, X., Cheerambathur, D., Gassmann, R., Suzuki, A., Lawrimore, J., Desai, A., and Salmon, E.D. (2013). Spindle assembly checkpoint proteins are positioned close to core microtubule attachment sites at kinetochores. J. Cell Biol. 202, 735-746.

Wan, X., O’Quinn, R.P., Pierce, H.L., Joglekar, A.P., Gall, W.E., DeLuca, J.G., Carroll, C.W., Liu, S., Yen, T.J., McEwen, B.F., et al. (2009). Protein Architecture of the Human Kinetochore Microtubule Attachment Site. Cell 137, 672-684.

Welburn, J.P.I. (2013). The molecular basis for kinesin functional specificity during mitosis. Cytoskeleton 70, 476-493.

Wood, K.W., Lad, L., Luo, L., Qian, X., Knight, S.D., Nevins, N., Brejc, K., Sutton, D., Gilmartin, A.G., Chua, P.R., et al. (2010). Antitumor activity of an allosteric inhibitor of centromere-associated protein-E. Proc. Natl. Acad. Sci. 107, 5839-5844.

Yardimci, H., van Duffelen, M., Mao, Y., Rosenfeld, S.S., and Selvin, P.R. (2008). The mitotic kinesin CENP-E is a processive transport motor. Proc. Natl. Acad. Sci. 105, 60166021.

Yen, T.J., Compton, D.A., Wise, D., Zinkowski, R.P., Brinkley, B.R., Earnshaw, W.C., and Cleveland, D.W. (1991). CENP-E, a novel human centromere-associated protein required for progression from metaphase to anaphase. EMBO J. 10, 1245-1254.

Zhernov, I., Diez, S., Braun, M., and Lansky, Z. (2020). Intrinsically Disordered Domain of Kinesin-3 Kif14 Enables Unique Functional Diversity. Curr. Biol. 30, 3342-3351.e5. 


\section{Figure legends}

Figure 1. The first predicted coiled-coil of human CENP-E weakly facilitates dimerisation of motor domains. (A) Coiled-coil prediction of full-length CENP-E by Paircoil2. Dashed vertical lines represent truncations. (B) Constructs used in this study. KT = kinetochore binding domain, MT = second microtubule binding site, GCN4 = GCN4 leucine zipper domain, His = hexahistidine tag, $\mathrm{mNG}=\mathrm{mNeonGreen}$. (C) Schematic representation of a single molecule motility assay. (D) Kymographs of CENP-E 483 and K560-GFP at indicated nanomolar concentrations for motility assays. (E) Native PAGE analysis of purified CENP- $E_{483}$ oligomeric status. $M=$ monomer, $D=$ dimer. $(F)$ Histogram representation of velocities for CENP-E $E_{483}(n=346)$ at $50 \mathrm{nM}$ fit to a single gaussian distribution $\left(r^{2}=0.978\right)$. (G) 1 - cumulative frequency distribution of run lengths for $C_{E N P-E_{483}}$ at $50 \mathrm{nM}(n=346)$ fit to a single exponential decay $\left(r^{2}=0.982\right)$. $(H) 1$ - cumulative frequency distribution of residency times for CENP- $E_{483}$ at $50 \mathrm{nM}(\mathrm{n}=346)$ fit to a single exponential decay $\left(r^{2}=0.990\right)$.

Figure 2. Stable CENP-E dimers are robustly processive in vitro. (A) Coomassie stained gel of purified CENP-E $483 \mathrm{Lz}$ and CENP-E $\mathrm{E}_{754}$ after SDS-PAGE. Arrowheads indicate purified

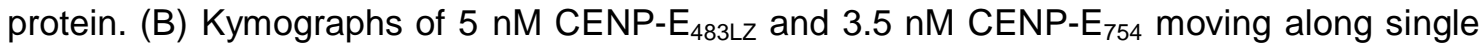
microtubules. (C) Schematic representation of photobleaching and intensity analysis assay. (D) Histogram distribution of CENP- $\mathrm{E}_{483 \mathrm{Lz}}$ velocities $(\mathrm{n}=774)$ fit to a single guassian distribution $\left(r^{2}=0.992\right)$. (E) 1 - cumulative frequency of run lengths measured for CENP$E_{483 L z}(n=774)$ and fit to a single expontential distribution $\left(r^{2}=0.986\right)$. $(F) 1$ - cumulative frequency of residency times measured for CENP- $E_{483 L z}(n=774)$ and fit to a single expontential distribution $\left(r^{2}=0.969\right)$. (G) Histogram distribution of CENP- $E_{754}$ velocities $(n=$ 289) fit to a single guassian distribution $\left(r^{2}=0.996\right)$. (H) 1 - cumulative frequency of run lengths measured for CENP- $E_{754}(n=289)$ and fit to a single expontential distribution $\left(r^{2}=\right.$ 0.993). (I) 1 - cumulative frequency of residency times measured for CENP-E $E_{754}(n=289)$ and fit to a single expontential distribution $\left(r^{2}=0.966\right)$. (J) Example 4-step photobleaching trace of CENP- $E_{754}$. (K) Histogram distribution of CENP- $E_{754}$ bleaching steps $(n=187)$. (L) Initial fluorescence intensity distribution of CENP- $E_{754}(n=88)$ and K560-2mNG $(n=117)$.

Figure 3. Full-length human CENP-E is a processive motor. (A) Coomassie stained gel of purified CENP-E $E_{F L}$ after SDS-PAGE. (B) Histogram distribution for microtubule gliding velocities of CENP-E $E_{F L}(n=93)$. (C) Example of a kymograph showing a single CENP-E $E_{F L}$ dimer moving along a microtubule. CENP- $E_{F L}$ was imaged at $12.5 \mathrm{nM}$. (D) Histogram distribution of CENP-E $E_{F L}$ velocities $(n=61)$ fit to a single guassian distribution $\left(r^{2}=0.958\right)$. (E) 1 - cumulative frequency of run lengths measured for CENP- $E_{F L}(n=61)$ and fit to a 
single expontential distribution $\left(r^{2}=0.951\right)$. (F) 1 - cumulative frequency of residency times measured for CENP-E $E_{F L}(n=61)$ and fit to a single expontential distribution $\left(r^{2}=0.995\right)$. $(G)$ Example 2-step photobleaching trace of CENP- $E_{\mathrm{FL}}$. $(\mathrm{H})$ Histogram distribution of CENP-E $\mathrm{F}_{\mathrm{FL}}$ bleaching steps $(n=102)$. (I) Initial fluorescence intensity distribution of CENP-E $E_{F L}(n=102)$.

Figure 4. The non-motor regions of human CENP-E regulate processive motility. (A)

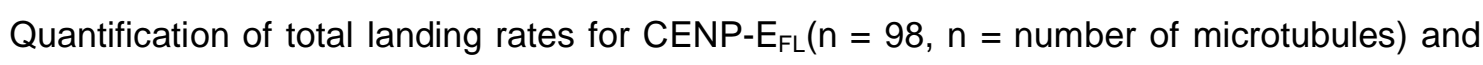
CENP-E $_{754}$ ( $n=100, n=$ number of microtubules). Welch's t-test, $p<0.0001$. (B) Quantification of processive landing rates for CENP-E $\mathrm{F}_{\mathrm{FL}}(\mathrm{n}=98, \mathrm{n}=$ number of microtubules) and CENP- $E_{754}(n=100, n=$ number of microtubules). Welch's t-test, $p<0.0001$. (C) Model of full-length CENP-E regulation. (i) In the absence of activating cargoes or post-translational modifications, CENP-E does not productively interact with microtubules and processive motility is blocked by autoinhibition. (ii) Once activated, CENP-E is capable of long-lasting processive motility required for transport of chromosomes in prometaphase, sorting of spindle microtubules and stabilisation of end-on kinetochore microtubule attachments.

Figure S1. CENP-E ${ }_{483}$ elutes as a single peak during size exclusion chromatography. (A) Elution profile of $\mathrm{CENP}_{-\mathrm{E}_{483}}$ from size exclusion chromatography. CENP-E $\mathrm{E}_{483}$ eluted as a single peak marked by an asterisk $\left(^{*}\right)$. (B) Coomassie stained gel showing purified CENP$\mathrm{E}_{483}$ after SDS-PAGE.

Movie 1. Single molecule motility of $\mathrm{CENP}-\mathrm{E}_{483 \mathrm{Lz}}$. In vitro reconstitution of CENP-E $\mathrm{E}_{483 \mathrm{LZ}}$ motility. Time lapse imaging of CENP-E $\mathrm{E}_{483 \mathrm{Lz}}$ was overlayed onto a single reference snapshot of GMPCPP-stabilised rhodamine microtubules taken from the same field of view, as a reference for microtubule localisation. Scale bar $=2 \mu \mathrm{m}$.

Movie 2. Single molecule motility of $\mathrm{CENP}-\mathrm{E}_{754}$. In vitro reconstitution of $\mathrm{CENP}-\mathrm{E}_{754}$ motility. Time lapse imaging of $\mathrm{CENP} \mathrm{E}_{754}$ was overlayed onto a single reference snapshot of GMPCPP-stabilised rhodamine microtubules taken from the same field of view, as a reference for microtubule localisation. Scale bar $=2 \mu \mathrm{m}$.

Movie 3. Microtubule binding, pivoting and gliding by CENP-E $E_{\mathrm{FL}}$. Behaviour of GMPCPP-stabilised rhodamine microtubules on a coverslip immobilised with CENP-E $\mathrm{FL}_{\mathrm{FL}}$. Scale $=4 \mu \mathrm{m}$.

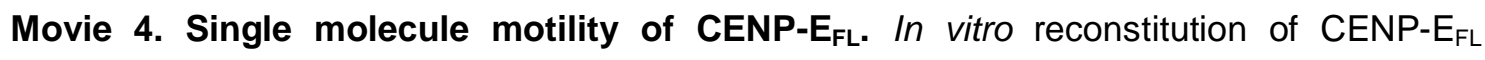
motility. Time lapse imaging of CENP- $\mathrm{E}_{\mathrm{FL}}$ was overlayed onto a single reference snapshot of 
bioRxiv preprint doi: https://doi.org/10.1101/2022.01.21.477187; this version posted January 21, 2022. The copyright holder for this preprint (which was not certified by peer review) is the author/funder, who has granted bioRxiv a license to display the preprint in perpetuity. It is made available under aCC-BY 4.0 International license.

GMPCPP-stabilised rhodamine microtubules taken from the same field of view, as a reference for microtubule localisation. Scale bar $=2 \mu \mathrm{m}$. 
bioRxiv preprint doi: https://doi.org/10.1101/2022.01.21.4771\&7; this version 19 sted January 21,2022. The copyrightholder for this preprint (which was not certified by peer review) is the author/funder, who has granted biokxiv a license to display the preprint ih peipetuity. It is made

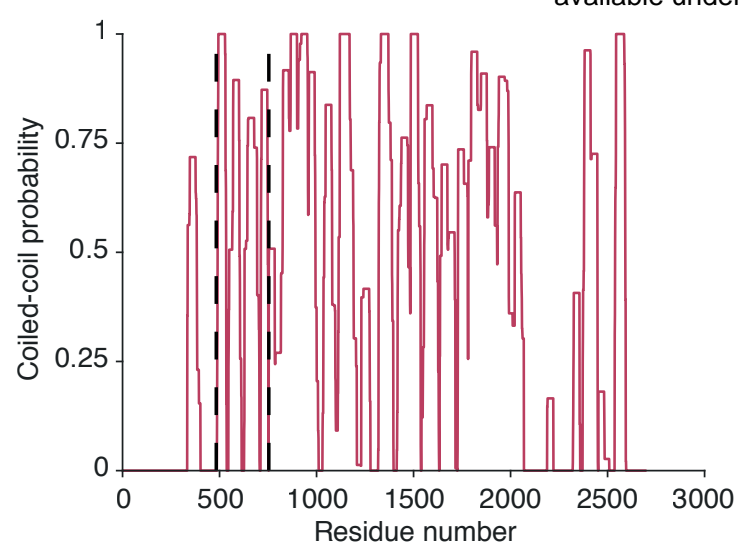

Full-length

2701 aa

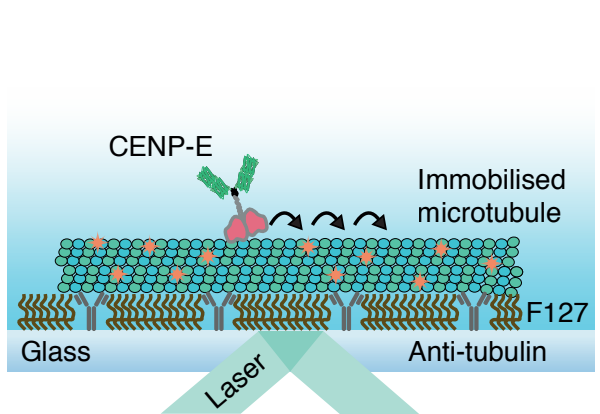

D

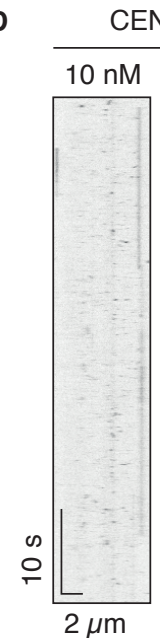

CENP-E $_{\mathrm{FL}}$

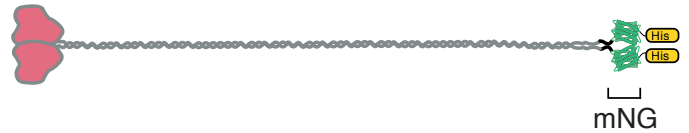

mNG

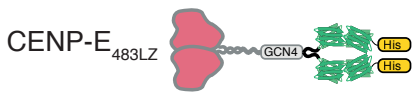

CENP-E

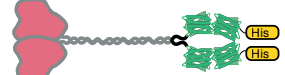

$\mathbf{F}$

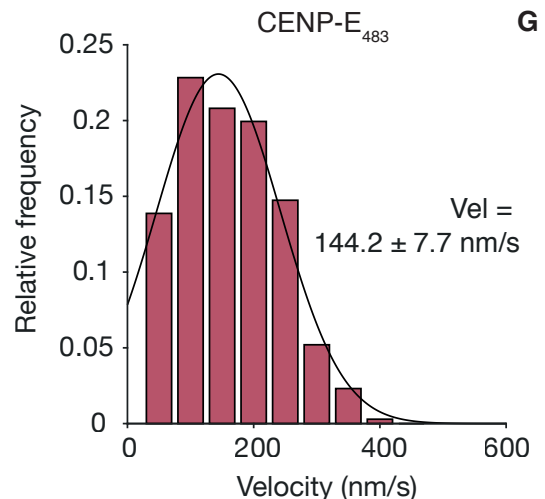

G

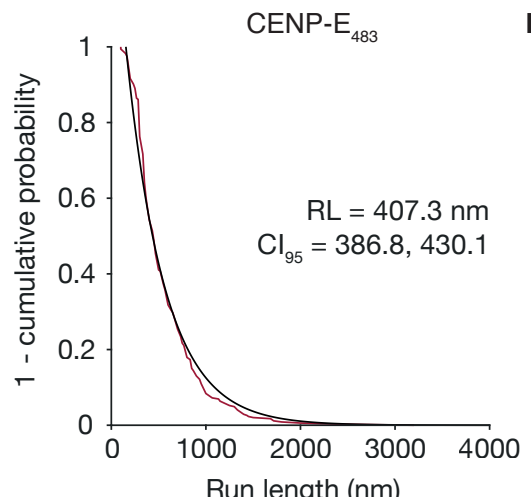

E CENP-E ${ }_{483}$

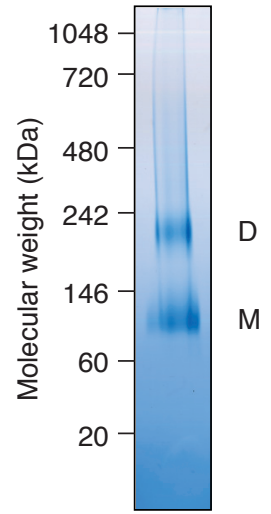

4 - $16 \%$ NATIVE PAGE

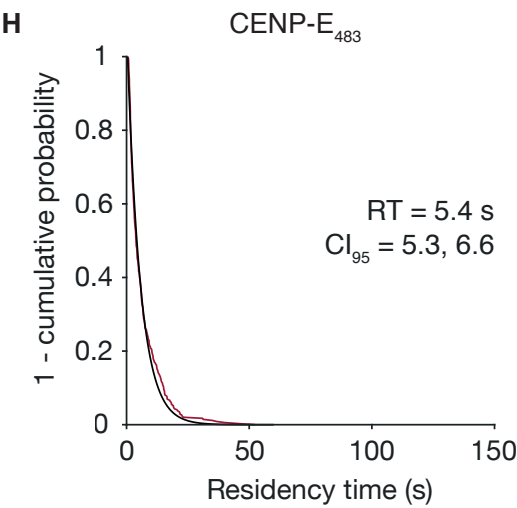

Figure 1 
bioRxiv preprint doi: https://doi.drg910.1101/2022.01.21.477187; this version posted January 21, 2022. The copyright holder for this preprint (which was not certified by peer rewFet) is the author/funder, who has granted bioRxiv a license to display the preprint in perpetuity. It is made
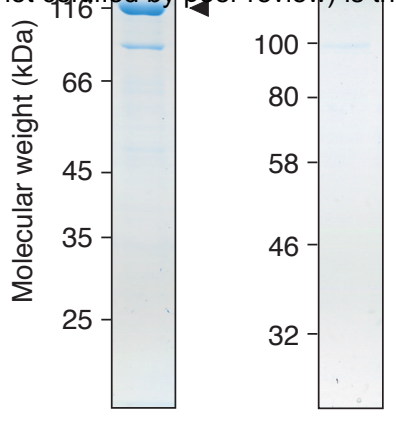
available under aCC-B 4.0 International license.
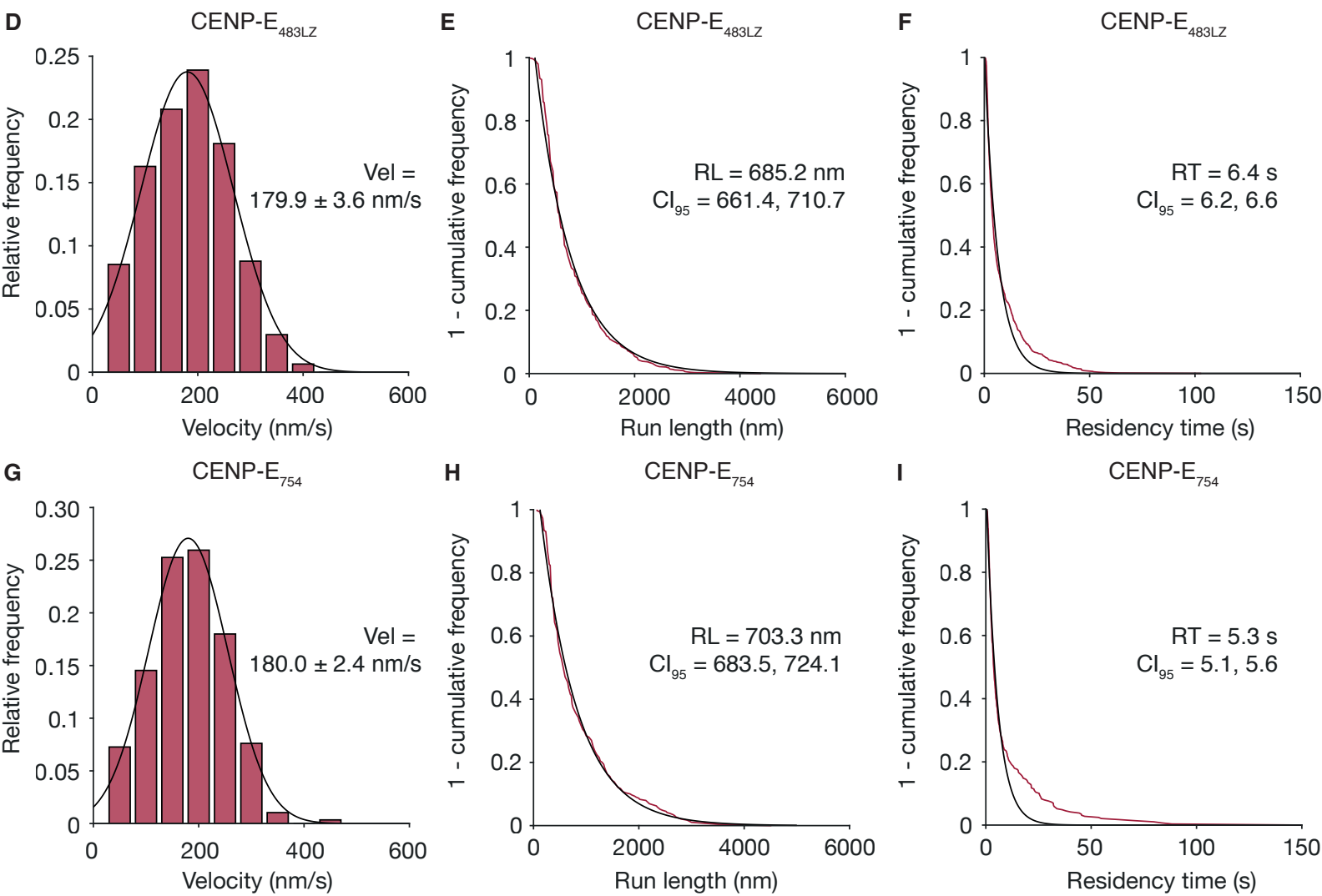

H

CENP-E
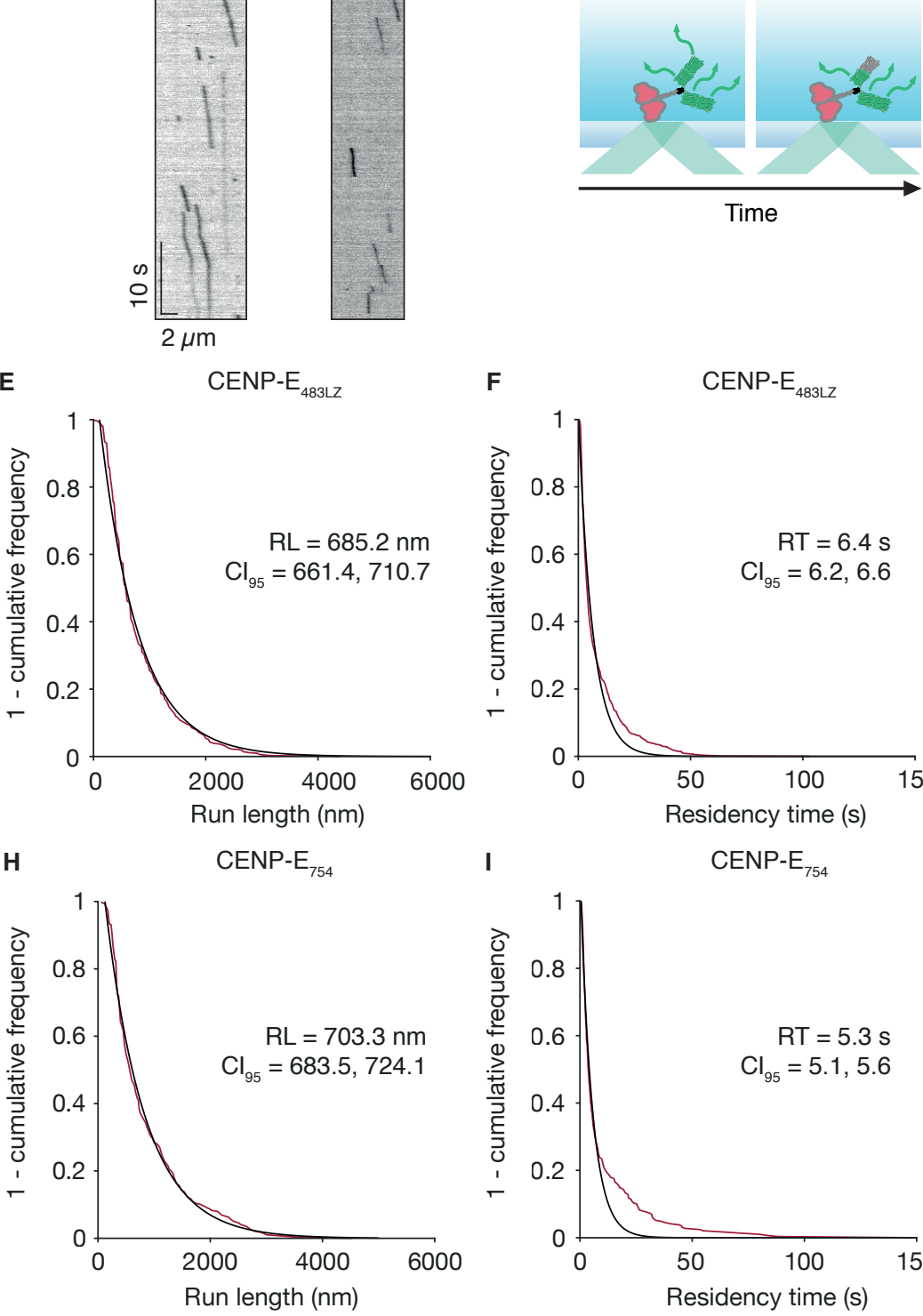

CENP-E ${ }_{754}$
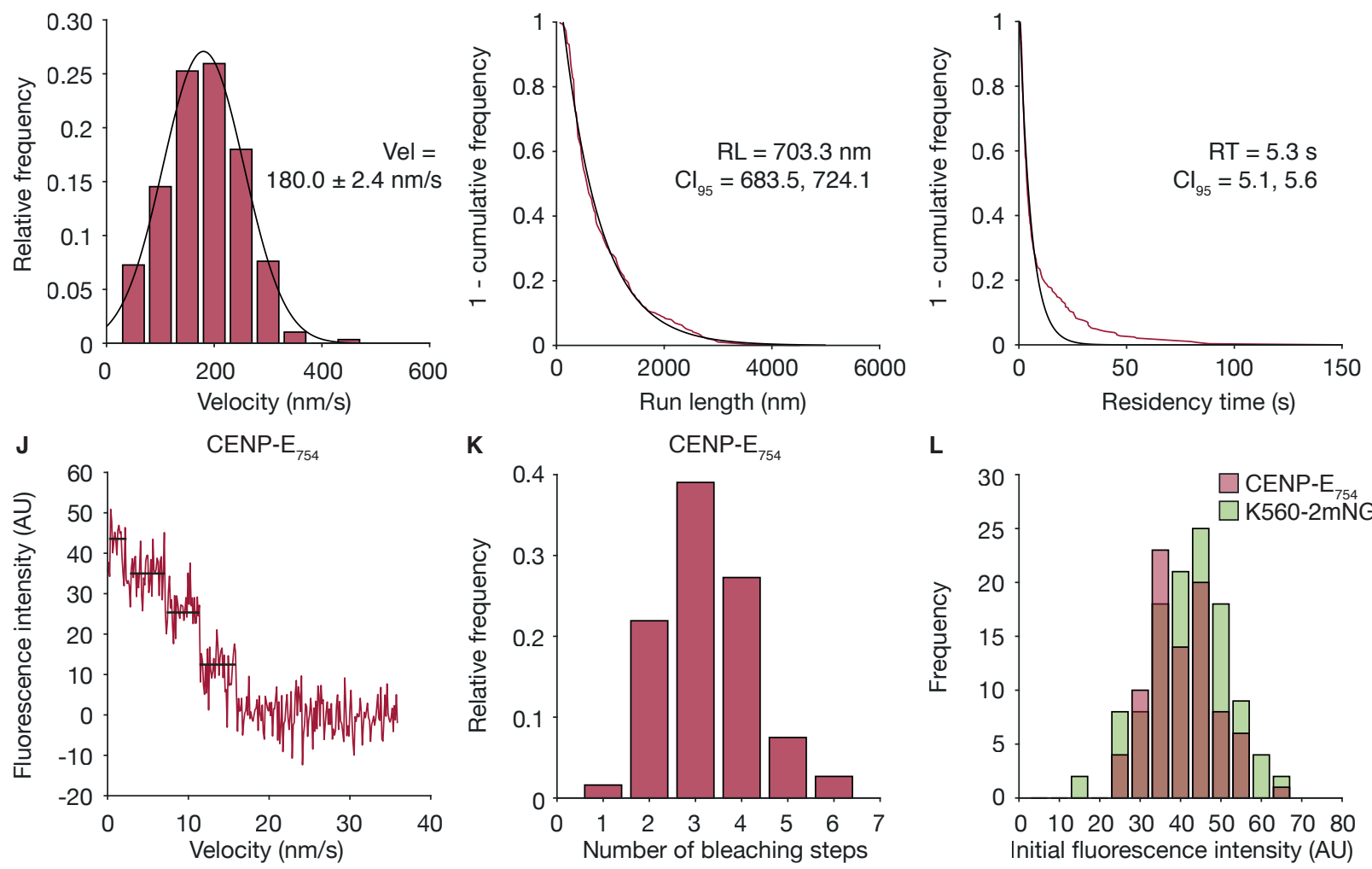

Figure 2 
A

CENP-E $_{\mathrm{FL}}$

B

C CENP-E

bioRxiv preprint doi: https://doi.org/10.1101/2022.01.21.477187; this version posted January 21, 2022. The copyright holder for this preprint (which was not certified by peer review) is the author/funder, whethof-granted bioRxiv a license to display the preprint in perpetuity. It is made
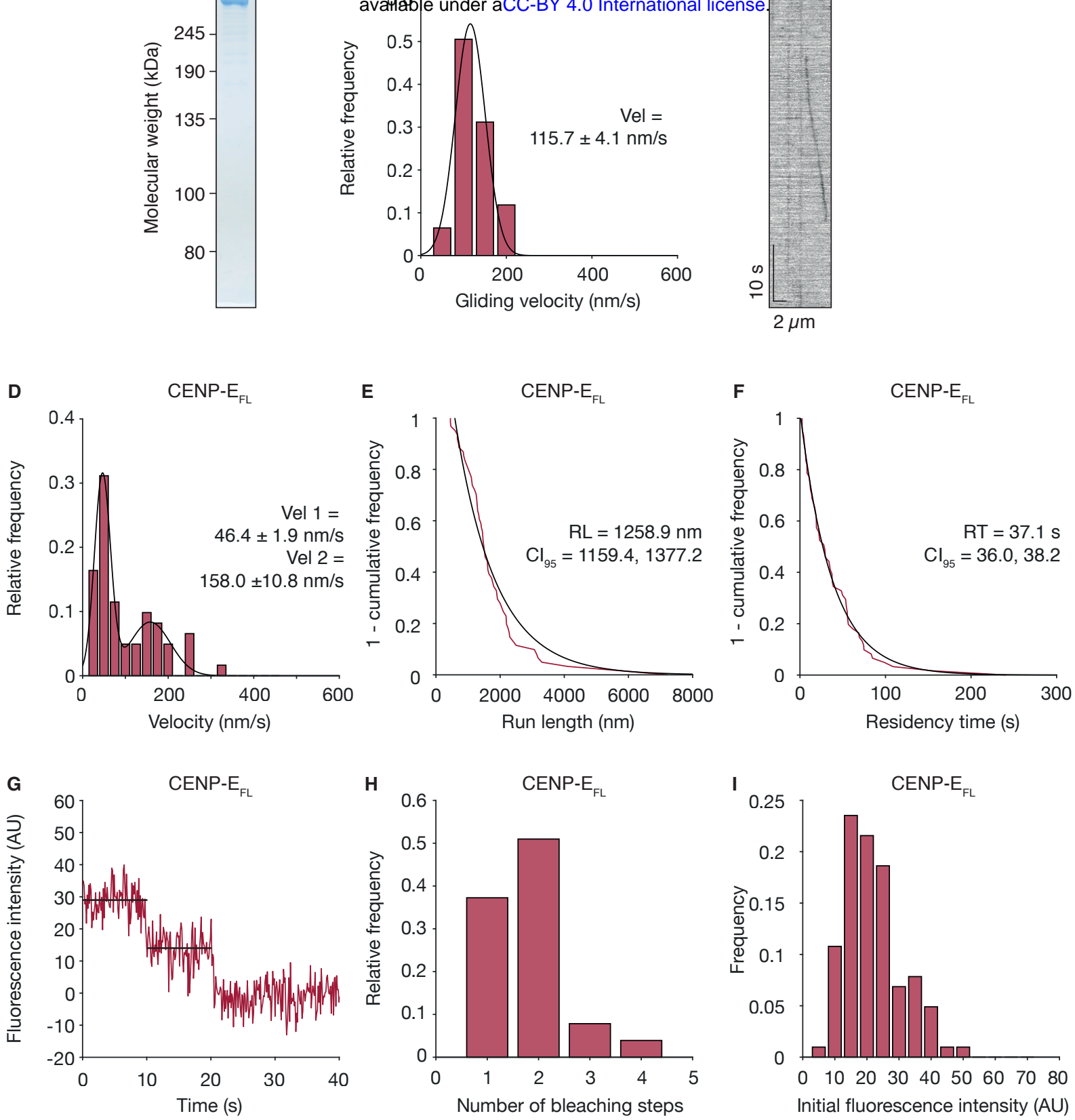

Figure 3 
bioRxiv preprint doi: https://doi.org/10.1101/2022.01.21.477187; this version posted January 21, 2022. The copyright holder for this preprint (which was not certified by peer review) is the author/funder, who has granted bioRxiv a license to display the preprint in perpetuity. It is made A B available under aCC-BY 4.0 International license.
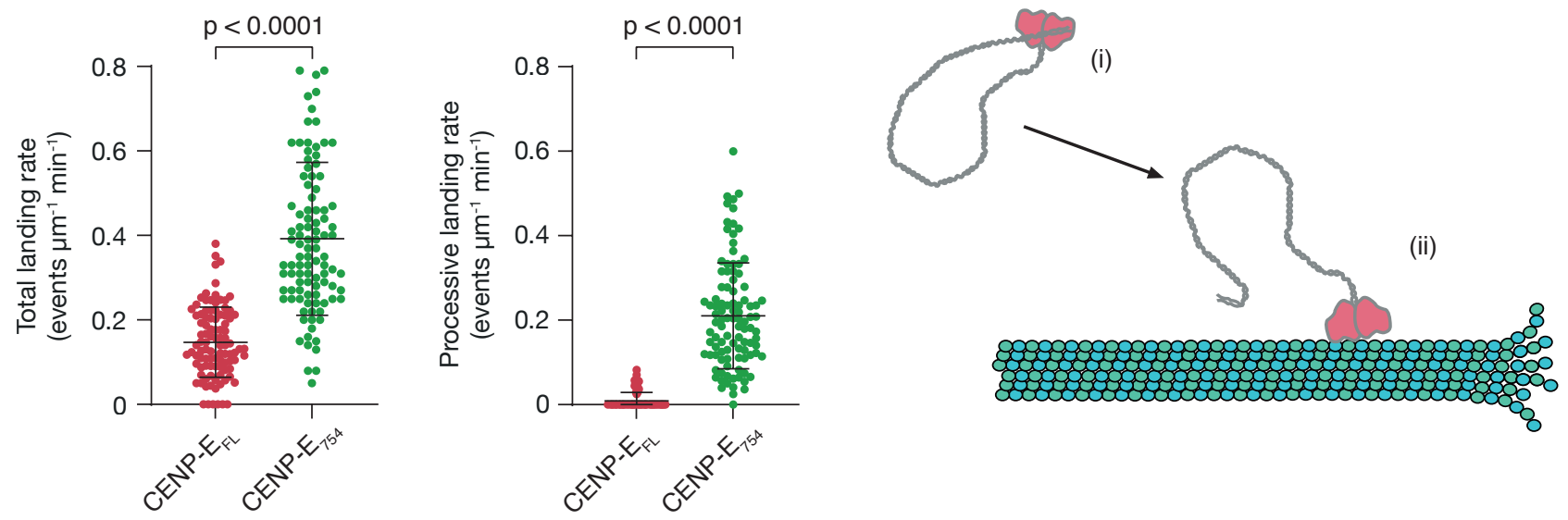

\section{Figure 4}

